\title{
Genetic characterization based on the D-loop MtDNA and the TSPY genes of the Dwarf Siamang (Hylobates klossii) of Mentawai Island, Indonesia
}

\author{
RIZKA HASANAH ${ }^{1, \bullet}$,UUS SAEPULOH ${ }^{2}$, DYAH PERWITASARI-FARAJALLAH ${ }^{2,3}$, WALBERTO SINAGA ${ }^{4}$, \\ YOHANA TRI HASTUTI ${ }^{4}$, DONDIN SAJUTHI ${ }^{5, \vee v}$ \\ ${ }^{1}$ Primatology Program, Graduate School, Institut Pertanian Bogor. Jl. Lodaya II No. 5, Bogor 16151, West Java, Indonesia. Tel: +62-251-8353386, \\ vemail: rizkhasanah@gmail.com \\ ${ }^{2}$ Primate Research Center, LPPM IPB. Institut Pertanian Bogor. Jl. Lodaya II No. 5, Bogor 16151, West Java, Indonesia \\ ${ }^{3}$ Department of Biology, Faculty of Mathematics and Natural Sciences, Institut Pertanian Bogor. Jl. Meranti Kampus IPB Dramaga. Bogor 16680, West \\ Java, Indonesia \\ ${ }^{4}$ Taman Safari Indonesia. J1. Kapten Harun Kabir No. 724, Cisarua, Bogor 16750, West Java, Indonesia \\ ${ }^{5}$ Departement of Pathology and Reproduction Clinic, Faculty of Veterinary Medicine, Institut Pertanian Bogor. Jl. Agatis Kampus IPB Dramaga, Bogor \\ 16680, West Java, Indonesia. Tel: +62-251-8629469, ^^email: sajuthi@indo.net.id
}

Manuscript received: 14 December 2019. Revision accepted: 31 May 2020.

\begin{abstract}
Hasanah R, Saepuloh U, Perwitasari-Farajallah D, Sinaga W, Hastuti Y, Sajuthi D. 2020. Genetic characterization based on the D-loop MtDNA and the TSPY genes of the Dwarf Siamang (Hylobates klossii) of Mentawai Island, Indonesia. Biodiversitas 21: 2854-2861. Hylobates klossii is an endemic primate on the Mentawai Island, Indonesia that categorized as endangered species due to fragmentation, illegal hunting, and habitat loss. This study aimed to analyze the genetic characterization of $H$. klossii based on maternal and paternal lineages. The samples were collected from TSI (Bogor, Indonesia) cage consist of two males and two females (blood and fecal of four individuals) and Siberut Island, Mentawai, West Sumatra, Indonesia from one unknown gender (one individual fecal sample). PCR amplification was carried out on DNA and cDNA samples using specific primers for D-loop MtDNA and TSPY genes. The amplicon was analyzed with MEGA-7. The dimensional structure model of the TSPY protein was determined using I-TASSER and visualized with PyMol. The maternal analysis showed five samples consisted of four haplotypes revealed that Nam-nam and April were identic with $0 \%$ genetic distance. It's revealed that Nam-nam and April were mother and son. The paternal analysis of two $H$. klossii males revealed that April was the closest relative to H. muelleri (99.56\% identity) and Gou-gou to $H$. klossii (100\% identity). Characterization of partial TSPY gene (990 bp) of April and Gou-Gou indicated four amino acids mutation, causing the shift in-amino acid structure position. The results assumed that April was a cross-breeding between $H$. klossii female and $H$. muelleri male. This genetic characterization is expected to support the conservation efforts through recommendations for good management in $H$. klossii preservation.
\end{abstract}

Keywords: D-loop, hybrid, Hylobates klossii, I-TASSER, TSPY

Abbreviations: Ala (A): Alanine, Asn (N): Asparagine, Asp (D): Aspartate acid, bp: basepair, D-loop: displacement loop, Glu (E): Glutamic Acid, Gly (G): Glycine, MtDNA: mitochondrial DNA, Pro (P): Proline, Ser (S): Serine, Thre (T): Threonine, TSI: Taman Safari Indonesia, TSPY: Testis specific protein in the Y chromosome

\section{INTRODUCTION}

Dwarf siamang (Hylobates klossii) is an endemic primate species on the Mentawai island. It is locally named Bilou. Hylobates klossii has a small body with bodyweight ranging from 5.5 to $7.5 \mathrm{~kg}$, body length $\pm 45 \mathrm{~cm}$, black hair covering the entire body, brachiation, arboreal and communicates through vocalization with other tribe members (Whittaker 2005). The distribution of H. klossii is limited to large islands in Mentawai, such as Siberut, Sipora, North Pagai, and South Pagai. H. klossii population is estimated to around 20,000-25,000 individuals, out of which 6,206-17,713 individuals are in the Siberut National Park (Whittaker 2005; Quinten et al. 2015). H. klossii is threatened by deforestation and hunting so the habitat has decreased, and its population has declined by $49-59 \%$ since the last survey in 1980 (Whittaker 2005). Dwarf siamang is considered as an endangered species (Whittaker and Geissmann 2008). Hylobates klossii is registered in the CITES Appendix I/2001 and protected under the Regulation of the Minister of Environment and Forestry of the Republic of Indonesia Number P.106Menlhk/Setjen/ Kum.1/12/2018.

Conservation is an effort to protect the habitat, preserve the diversity and sustainable utilize species population from extinction. Referring to habitat degradation and changing in vegetation composition, primates require habitat, population, and individual management based on scientific understanding of the biology of the species (Singh et al. 2012). The conservation of primates can be done within their habitat (in-situ) or in captivity (ex-situ). Ex-situ conservation aims to support in situ conservation. It 
can be done to reduce the threat of extinction in the wild. Species breeding programs one of the programs that can maintain and produce pure offspring aimed at protecting genetic resources and increasing populations. Hylobates klossii has a small population so that ex-situ conservation can be done to increase the population in nature (Masy'ud and Ginoga 2016).

Molecular analysis can be performed to obtain information regarding the effective population size, heredity, kinship, sex, distribution, population structure, and gene flow (Ferreira et al. 2012). In the analysis of kinship and evolution, the DNA that is often used is mitochondrial DNA (mtDNA). The mitochondrial DNA is maternally inherited as a haploid with the size of is 16.6 $\mathrm{kb}$. Its rapid rate of evolution thus makes it is used in phylogenetic reconstruction, phylogeographic, and population genetic studies (Allendorf et al. 2012; Hu et al. 2015). The D-loop is a non-recombinant and non-coding area, playing a role in the replication and translation process so the mtDNA control region (D-loop region) is the most variable portion of the mammalian mtDNA genome than others (Hu et al. 2015). It has a hypervariable (HV) region consisting of $\mathrm{HV}-\mathrm{I}$ and $\mathrm{HV}$-II and the most polymorphic region of the human MtDNA genome (Mondal and Ghosh 2013). Those areas are extensively used in the study of molecular evolution at species and subspecies levels (Stoneking 2000).

In contrast to the mtDNA as a larger number of polymorphisms in its region widely used in molecular studies based on maternal (Kundu and Ghosh 2015), the Y chromosome is a non-recombinant gene that can reveal kinship according to paternal lineage (Eriksson et al. 2006). One specific gene on the $Y$ chromosome used to determine paternal inheritance is the TSPY (Testis-Specific Protein in the $Y$ Chromosome) gene. This specific Ychromosome showed relatively high nucleotide diversity indices in varied among the other chromosomal in gibbon (Chan et al. 2012). The complete sequence of the TSPY gene in dwarf siamang has not been documented; hence, it is needed to characterize the gene.

Biparental analysis is needed to analyze both maternal and paternal lineages based on the mtDNA D-loop and the TSPY gene, respectively, and characterize the structure of the TSPY protein-coding gene in dwarf siamang (Hylobates klossii) on Mentawai island. This genetic characterization is expected to support the conservation efforts through recommendations for good management in H. klossii preservation.

\section{MATERIALS AND METHODS}

\section{Time and place}

This research was conducted from October 2018 to September 2019. Samples of $H$. klossii were collected from Taman Safari Indonesia (TSI), Cisarua, Bogor, West Java, Indonesia and Siberut, Mentawai Islands, West Sumatra, Indonesia. Laboratory analysis was conducted at the Biotechnology Laboratory of the Primate Research Center (PSSP), LPPM IPB, Bogor, Indonesia.

\section{Procedures}

\section{Sample collection}

The samples in this study consisted of feces (five individuals) and blood (four individuals) collected in Siberut Island and TSI (Table 1). Fresh fecal samples 180$220 \mathrm{mg}$ were collected in the morning using a cotton bud and put into a tube containing $70 \%$ ethanol and Viral Transport Media (VTM) and stored in a cool box. Meanwhile, blood samples were taken at TSI. Two milliliters blood samples were taken and put into a blood tube with EDTA anticoagulant during general examination for H. klossii. Blood samples were stored in the freezer at $20^{\circ} \mathrm{C}$.

The animal code approved this study of ethics from the Institutional Animal Care and Use Committee (IACUC) Number IPB PRC-19-D007 and the Biorisk Commission of the Primate Research Center IPB Number 010-PL-PSSP03-2019.

\section{Nucleic acid isolation}

The DNA from feces and blood samples was extracted using QiaAmp ${ }^{\mathrm{TM}}$ DNA Extraction Stool and Blood mini kit (Qiagen, Hilden, Germany), according to manufacturer's protocol. The RNA extraction from blood samples was carried out using the RNAEasy mini kit (Qiagen, Hilden, Germany). cDNA was reverse transcriptase using the Superscript III cDNA synthesis (Invitrogen) kit. DNA and RNA concentrations were measured with NanoDrop ${ }^{\mathrm{TM}}$ One (Thermo Scientific).

\section{DNA Amplification}

PCR amplification of the mtDNA D-loop was performed using specific primers, GIBDLF3, and GIBDLR4. The TSPY gene was amplified using TSPY-A and TSPY-B primers, then further analyzed based on the cDNA sample using specific primers (Table 2). The PCR reaction consisted of $1 \mu \mathrm{L}$ of each 10 pmol $\mu \mathrm{L}^{-1}$ forward and reverse primer; $12.5 \mu \mathrm{L}$ of GoTaq Green Master Mix; 2.5-5 $\mu \mathrm{L}$ DNA template and nuclease-free water to a total volume of $25 \mu \mathrm{L}$. DNA and cDNA amplification was carried out using a Thermal Cycler machine (GeneAmp® PCR System 9700) with 40 cycles under the following conditions: denaturation at $94^{\circ} \mathrm{C}$ for 30 seconds, annealing (according to the Ta temperature of each primer) for 30 seconds to 1 minute and extension at $72{ }^{\circ} \mathrm{C}$ for 7 minutes. The PCR products were electrophoresed in $1.8 \%$ agarose gel and visualized using SYBR Safe (Invitrogen) under UV Gel Doc 2000 (Biorad). The bands were analyzed using the Quantity One program (Biorad). The PCR product was sequenced at $1^{\text {st }}$ BASE Laboratories Sdn Bhd (Malaysia).

Table 1. The list of feces and blood samples collected from Hylobates klossii

\begin{tabular}{llll}
\hline Name & Sex & Sample & Location \\
\hline Nam-nam & Adult female & Fecal and blood & TSI, Bogor \\
April & Juvenile male & Fecal and blood & TSI, Bogor \\
Lestari & Juvenile female & Fecal and blood & TSI, Bogor \\
Gou-gou & Juvenile male & Fecal and blood & TSI, Bogor \\
Bilou & Unknown & Fecal & Bekemen, \\
& & & Siberut \\
\hline
\end{tabular}




\section{Phylogeny analysis based on mtDNA and TSPY}

The nucleotide sequences were manually edited based on the chromatogram using the Bioedit program version 7.2.6 (Hall 1999). The alignment of the nucleotide sequences was carried out using the ClustalW program. The alignment results of the mtDNA, D-loop, and TSPY sequences were analyzed using the NCBI website (https: //blast.ncbi.nlm.nih.gov) by selecting the BLAST-N to identify the closest relatives. The nucleotide sequences obtained were analyzed using the MEGA-7 program (Kumar et al. 2016). Genetic distance estimation was determined using pairwise distance method with the pdistance model. The phylogenetic tree was constructed based on the NJ (Neighbor-joining) method with 1000 repetitions.

\section{Coding region characterization of the TSPY gene}

Nucleotide sequences of the TSPY gene were translated into amino acids through the ORF finder (https: //www.ncbi.nlm.nih.gov/orffinder). The difference in the nucleotide and amino acid sequences were compared and analyzed using Clustal W. The 3D structure modeling of amino acid was constructed through the I-TASSER program (https://zhanglab.ccmb.med.umich.edu/I-TASSER) (Yang and Zhang 2015). The PyMol program was used to visualize the protein structure.

\section{RESULTS AND DISCUSSION}

\section{Phylogeny analysis based on maternal lineage}

The 512 bp amplicon was obtained from the amplification of $H$. klossii's d-loop MtDNA. The aligned D-loop MtDNA nucleotide was $449 \mathrm{bp}$, consisting of 415 conserved regions, 34 variable regions with 12 parsimony regions, and 22 singletons. The gene target was in the HV-I region of 427 base pairs (1-427 of 449 base pairs) (ref. Ef363503.1), which was one part of the D-loop with high evolution rate. The HV-I region of the D-loop has a faster mutation rate than other regions. So, it is useful to understand intra-species relationships, studies of population genetic diversity, and the reconstruction of the past demographic history (Whittaker et al. 2007; Hu et al. 2015).
The sequencing of nucleotide bases supported by genetic distance analysis results showed that intra-species variations ranged from 0.00 to 0.047 (Table 3). Nam-nam and April had the smallest genetic distance, which was 0.00. It showed that Nam-nam and April had a very close (identic) relationship based on maternal lineage because they had the same MtDNA nucleotide sequence (conserved). Nam-nam and April are mother and son. They have a smaller genetic distance with Bilou (0.024) compared to Lestari and Gou-gou (0.045). The smaller the genetic distance, the lesser the difference in nucleotide bases. The greater the genetic distance, the greater the differences, and vice versa.

The results of the mtDNA D-loop analysis from five samples showed four haplotypes, as indicated by the distribution of $H$. klossii based on the phylogeny trees (Figure 1). The phylogeny analysis using the neighborjoining method revealed that Nam-Nam and April were in a cluster with dwarf siamang from the North and South Pagai, Bilou from Sipora, Gou-Gou from Pagai and Lestari from Siberut.

\section{Phylogeny of $\boldsymbol{H}$. klossii based on paternal lineage}

The TSPY fragment amplification results revealed 780 bp identified in two $H$. klossii male individuals, namely Gou-Gou and April. The nucleotide sequencing of the TSPY gene resulted in the overlapping nucleotide sequences of $746 \mathrm{bp}$, consisting of 737 conserved regions and 9 variable regions. Referring to the gene reference, the accession number JN871374.1 showed that the TSPY gene consisted of exon 1 (1-72 nt), intron 2 (73-675nt), and exon 2 (676-719nt). This result indicated that the TSPY region consisted of non-coding regions (introns).

Table 3. The genetic distance ( $p$-distance \%) of the Hylobates klossii based on the mitochondrial D-loop sequence

\begin{tabular}{llrrrrr}
\hline No. & Names of individuals & $\mathbf{1}$ & $\mathbf{2}$ & $\mathbf{3}$ & $\mathbf{4}$ & $\mathbf{5}$ \\
\hline 1 & Nam-Nam (TSI Bogor) & - & & & & \\
2 & April (TSI Bogor) & 0 & - & & & \\
3 & Lestari (TSI Bogor) & 0.045 & 0.045 & - & & \\
4 & Gou-Gou (TSI Bogor) & 0.045 & 0.045 & 0.040 & - & \\
5 & Bilou & 0.024 & 0.024 & 0.042 & 0.047 & - \\
& (Bekemen_Siberut) & & & & & \\
\hline
\end{tabular}

Table 2. Specific primers used in this study

\begin{tabular}{|c|c|c|c|c|}
\hline Primers & Primer sequence & Ta $*)$ & $\begin{array}{c}\text { Amplicon } \\
\text { (bp) }\end{array}$ & References \\
\hline GIBDLF3 & 5'CTTCACCCTCAGCACCCAAAGC 3' & & 512 & (Andayani et al. 2001) \\
\hline GIBDLR4 & 5'GGGTGATAGGCCTGTGAT C 3' & 56 & & \\
\hline TSPY-A & 5’AGCCAGGAAGGCCTTTTCTCG 3' & & 780 & (Chan et al. 2012) \\
\hline TSPY-B & 5'CCATGTAGCTCAGCATGTCTTCAT 3' & 60 & & \\
\hline TSPY1139F & 5'GCTGGTGTCTCACTCAACC 3' & 54 & 1000 & (Biotechnology Lab design with \\
\hline TSPY1739R & 5’TTGTCAGGGTTCTCTTCGTT 3' & & & reference XM_024240960.1) \\
\hline TSPY1509F & 5'ACCACCGACTACTTCGAGAC 3' & 52 & 800 & \\
\hline TSPY2109R & 5’TCСТTCСТCСТCATAGTTTCC 3’' & & & \\
\hline TSPY2058F & 5'ATCGAGCAAGATGAGGACAT 3' & 53 & 800 & \\
\hline TSPY2798R & 5'GAACTTGCTCAGAATTTTATTGG 3' & & & \\
\hline
\end{tabular}

Note : *Ta: annealing temperature 


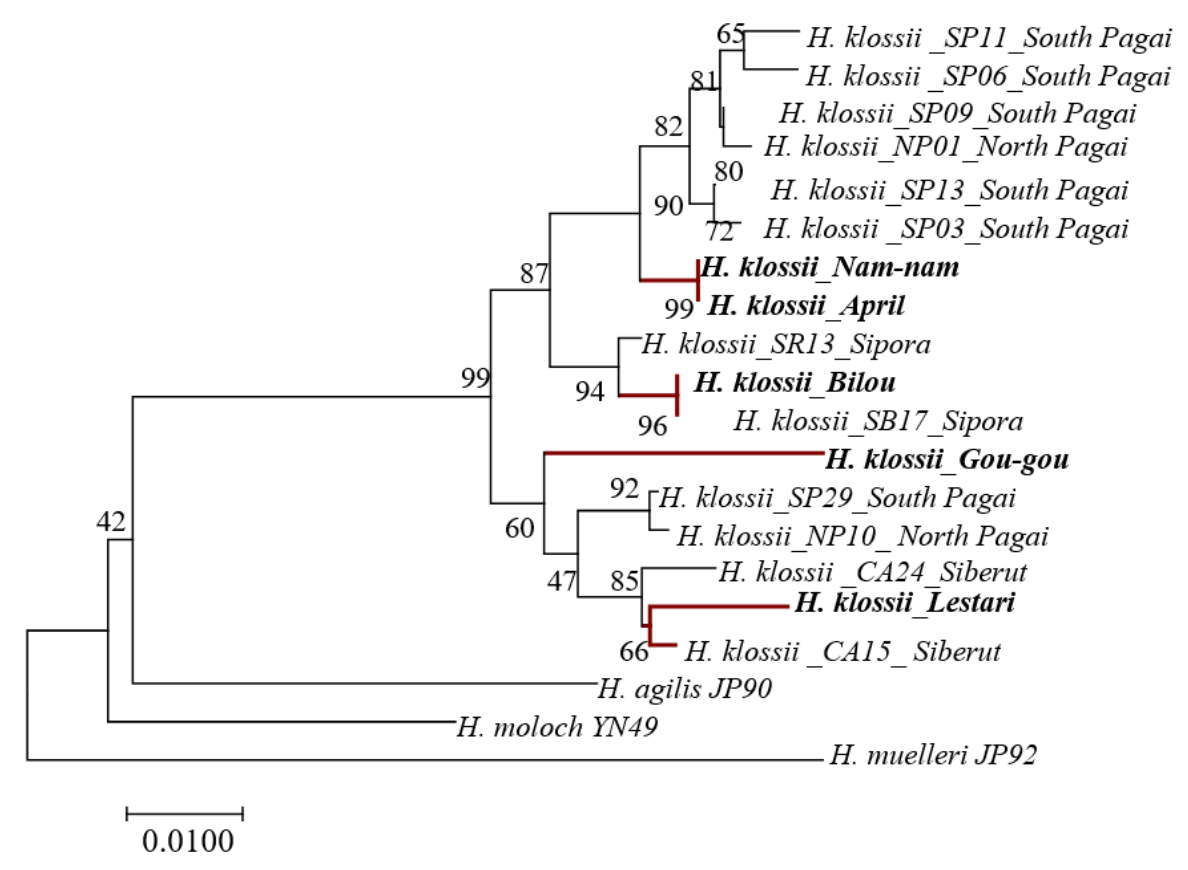

Figure 1. The phylogeny tree of Hylobates klossii based on D-loop mtDNA analysis using the Neighbor-joining method

The alignment of nucleotides based on BLAST showed that Gou-Gou had $100 \%$ identity similarity with the $H$. klossii (JN871377.1), while April had 99.56\% with $H$. muelleri (JN871377.1) (Table 4). The DNA mutations in individuals were determined by the transition (changes in fellow purines or fellow pyrimidines) and transversion (changes in purines to pyrimidines or vice versa) (Brown et al. 1979). The April individual comparison of the $H$. klossii (JN871377.1) and Gou-Gou based on nucleotide sequencing using MEGA revealed seven nucleotide changes in the forms of transition mutations at sites 129 (T/C), 387 (C/T), 510 (G/A), 540 (G/A), 561 (G/A) and 727 (G/A). Whereas, transversion mutations occurred at site 296 from purines to pyrimidines (A/T) (Table 4).

Nucleotide changes were in line with the genetic distance values in the p-distance method in April and GouGou compared with $H$. klossii and data from genebank (Table 5). The H. klossii Gou-gou had a genetic distance of 0.00 to the H. klossii* but had a genetic distance of 0.008 to April. April had a genetic distance value of 0.008 with H. klossii* and 0.005 to $H$. muelleri ${ }^{+}$, Meanwhile Gou-Gou has a genetic distance value of 0.010 to $H$. muelleri ${ }^{+}$. The resulting genetic distance values showed $H$. klossii April had a smaller genetic distance with $H$. muelleri ${ }^{+}$than with fellow H. klossii* (intraspecies).

The phylogeny analysis using the neighbor-joining method (Figure 2) showed that $H$. klossii individuals were divided into two clusters, namely $H$. klossii Gou-gou with similarities to $H$. klossii* (JN871377.1) (bootstrap value 98\%) and $H$. klossii April being in a group with $H$. muelleri $^{+}$(JN871374.1) (bootstrap value of 99\%).

\section{Characterization of the TSPY protein structure}

The analysis of the TSPY gene in the coding region was carried out to characterize the protein structure of the TSPY gene in two male individuals (April and Gou-Gou). The results of the cDNA amplification of the partial TSPY gene produced an amplicon of $990 \mathrm{bp}$. The alignment based on the nucleotide sequences of cDNA of origin between Gou-gou and April individuals had 99\% identity similarity.

The TSPY gene of 990 bp between Gou-Gou and April individuals (Table 6) went through changes in nucleotide bases. The mutations were in the forms of transversions in the 298 bases $(\mathrm{C} / \mathrm{G})$ and $841(\mathrm{~A} / \mathrm{T})$ and transitions in the 369, 397, $831(\mathrm{~A} / \mathrm{G})$ bases. Five nucleotide mutations produced changes in the composition of amino acids. The mutations in the nucleotide position 280 caused changes in site 100 amino acids from proline to alanine (Pro100Ala), position 397 changes in amino acids in the site 133 from asparagine to aspartic acid (Asn133Asp), position 831 changes in amino acids site 277 from glycine to glutamine (Gly277Glu) and the position 841 nucleotides undergo the site 281 in amino acids from threonine to serine (Thre281Ser). The position of 369 changes in nucleotides does not cause a change in the site 123 amino acid (Ala123Ala).

The change in amino acids in the TSPY gene between Gou-gou and April caused conformational changes in the predicted three-dimensional structure of the TSPY protein produced. The results of the alignment of the positions between the two structures (superimposed) indicated a change in the location of amino acids (Figure 3 ). 


\section{Discussion}

The results of the mtDNA D-loop analysis from five samples showed four haplotypes, as indicated by the distribution of $H$. klossii in four islands. Based on D-loop MtDNA nucleotide, there are no genetic differentiation between H. klossii in Siberut, Sipora, North Pagai and South Pagai islands. This assumed that Mentawai Islands had been not separated in a long time (Whittaker 2005). However, the TSPY gene showed differences which $H$. klossii named April was clustered with $H$. muelleri (JN871374.1). The differences in nucleotide genes in April based on the TSPY gene suggested hybrid mating from $H$. klossii females (Nam-nam ) with H. muelleri males.

Table 4. Variations of the TSPY nucleotide substitution between Hylobates klossii (BLAST) individuals

\begin{tabular}{|c|c|c|c|c|c|c|c|c|}
\hline \multicolumn{9}{|c|}{ Nucleotide Substitution } \\
\hline \multirow{3}{*}{ Names } & 1 & 2 & 3 & 5 & 5 & 5 & 7 & \multirow{3}{*}{ Identity (\%) } \\
\hline & 2 & 9 & 8 & 1 & 4 & 6 & 2 & \\
\hline & 9 & 6 & 7 & 0 & $\mathbf{0}$ & 1 & 7 & \\
\hline Gou-gou & $\mathrm{T}$ & $\mathrm{A}$ & $\mathrm{C}$ & $\mathrm{G}$ & G & $\mathrm{G}$ & G & 100 \\
\hline H. klossii (JN871377.1) & $\mathrm{T}$ & A & $\mathrm{C}$ & G & G & G & G & \\
\hline April & C & $\mathbf{T}$ & $\mathbf{T}$ & $\mathbf{A}$ & $\mathbf{A}$ & $\mathbf{A}$ & $\mathbf{A}$ & 99.56 \\
\hline H. mиelleri (JN871374.1) & $\mathrm{C}$ & $\mathrm{T}$ & $\mathrm{T}$ & A & A & G & A & \\
\hline
\end{tabular}

Table 5. The genetic distance (p-distance \%) of Hylobates klossii to other non-human primates species based on the TSPY gene

\begin{tabular}{|c|c|c|c|c|c|c|c|c|c|c|c|}
\hline No. & Species names & 1 & 2 & 3 & 4 & 5 & 6 & 7 & 8 & 9 & 10 \\
\hline 1 & H. sapiens & - & & & & & & & & & \\
\hline 2 & P. troglodytes & 0.504 & - & & & & & & & & \\
\hline 3 & M. fascicularis & 0.159 & 0.521 & - & & & & & & & \\
\hline 4 & S. syndactylus & 0.077 & 0.501 & 0.153 & - & & & & & & \\
\hline 5 & H. lar & 0.074 & 0.496 & 0.144 & 0.025 & - & & & & & \\
\hline 6 & H. klossii_April & 0.076 & 0.494 & 0.149 & 0.026 & 0.015 & - & & & & \\
\hline 7 & H. klossii_Gou-gou & 0.076 & 0.499 & 0.144 & 0.023 & 0.010 & 0.008 & - & & & \\
\hline 8 & H. klossii* & 0.076 & 0.499 & 0.144 & 0.023 & 0.010 & 0.008 & 0.000 & - & & \\
\hline 9 & H. muelleri ${ }^{+}$ & 0.077 & 0.496 & 0.151 & 0.028 & 0.016 & 0.005 & 0.010 & 0.010 & - & \\
\hline 10 & H. agilis & 0.077 & 0.499 & 0.148 & 0.028 & 0.013 & 0.011 & 0.007 & 0.007 & 0.013 & - \\
\hline
\end{tabular}

Note: ${ }^{*}{ }^{+}$is a comparative individual that use to compare with April dan Gou-gou (data were taken from Gene Bank for comparison).

Table 6. Differences in the nucleotide base and individual amino acids of Gou-Gou and April of the TSPY gene cDNA

\begin{tabular}{ccccccc}
\hline \multirow{2}{*}{ Names } & \multirow{2}{*}{ Type of changes } & \multicolumn{4}{c}{ Nucleotide positions } \\
\cline { 3 - 7 } & Nucleotide & 298 & G69 & G97 & 831 & 841 \\
\hline \multirow{2}{*}{ Gou-gou } & Amino Acid & Pro (P) & Ala (A) & AAT & GGG & ACG \\
& Nucleotide & GCC & GCG & GAT & Gly (G) & Thr (T) \\
\multirow{2}{*}{ April } & Amino Acid & Ala (A) & Ala (A) & Asp (D) & Glu (E) & TCG \\
& & &
\end{tabular}

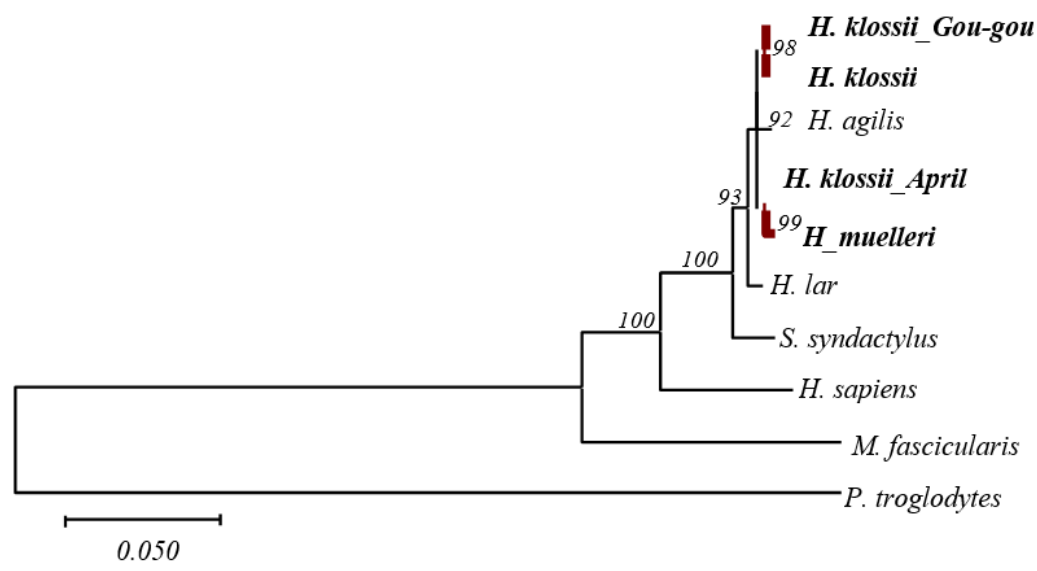

Figure 2. The phylogeny analysis of the TSPY gene based on the neighbor-joining method 


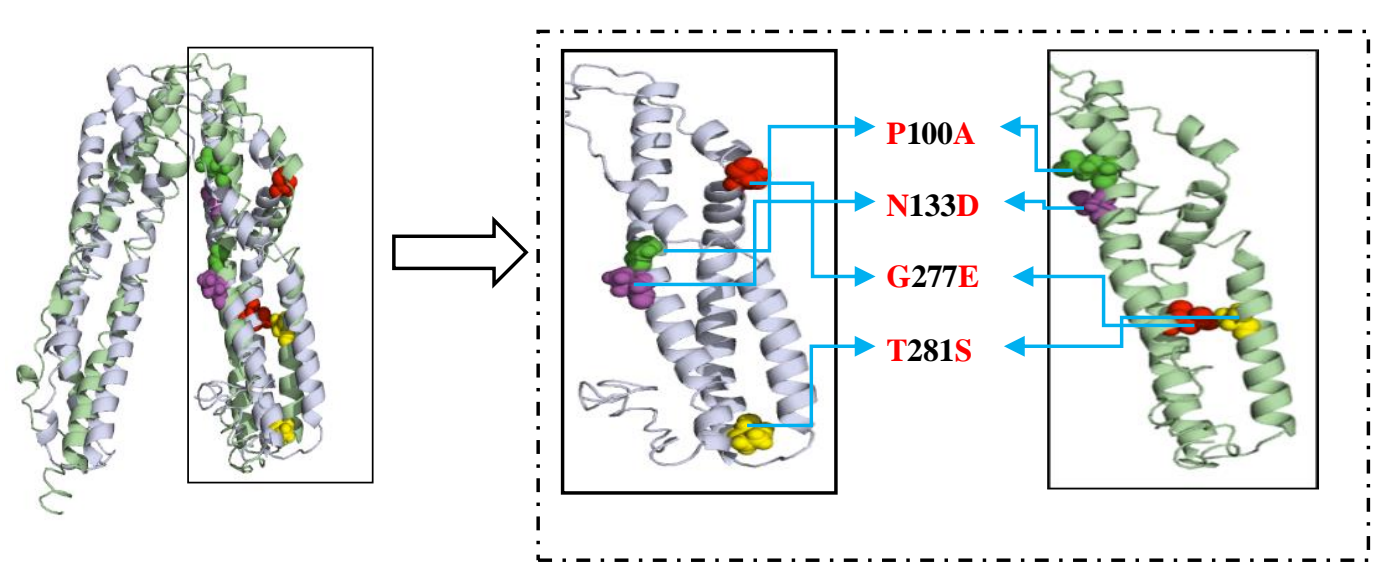

A

B

Figure 3. Prediction of three-dimensional structure models of partial cartoon TSPY forms using the I-TASSER program visualized with the PyMol program. A. Position alignment (superimposed) TSPY protein structure of individual Gou-gou (gray) and April (light green), B. Position of amino acids undergoing mutations (spherical shape)

Morphologically, H. klossii April has the same characteristics as $H$. muelleri individuals in terms of face and head shapes (Figure 4). The genus Hylobates has many similarities in character such as skull shape, intermembrane index, and genital features (Groves 2001) such as same humeral long with bowed humeral shafts (Holliday and Friedl 2013). H. klossii has a grey-brown hair color, blackish underside, crown with a dark patch surrounded by a ring of bright fur around its face while $H$. klossii had all black hair and monochromatic (Groves 1971). As a result of hybrid tillers, April was a black monochromatic shorthaired with white eyebrows. April has the same characteristics as elder males, namely the presence of white eyebrows, relatively thick back hair like those of $H$. muelleri (male elder), and larger body size than normal dwarf gibbons. Based on observation, April has the bodyweight about $6.6 \mathrm{~kg}$ with height about $77 \mathrm{~cm}$ while others H. klossii has bodyweight about $1.7-5.7 \mathrm{~kg}$ with a height $55-76 \mathrm{~cm}$. H. muelleri has a bodyweight of about 5.8 $\mathrm{kg}$ with a height of about $54 \mathrm{~cm}$. Body mass and height of April were above the average of $H$. klossii, thus it makes more evidence that he is a hybrid mating between $H$. klossii female and $H$. muelleri male (Figure 4).

Hybridization is the marriage of individuals from two different populations or groups which are differentiated based on one or more inherited characters. The success of producing offspring from hybridization is due to individual elders that are still in one genus Hylobates and have the same number of chromosomes $(2 \mathrm{n}=44)$ (Groves 2001). Hybridization between species can occur due to forest fragmentation and habitat destruction, making it difficult for a species to find the same species (Detwiler et al. 2005). Hybrid cases in captivity occur due to the limited number of similar individuals and the location of adjacent species in cages.

Hybrid results occur with and without introgression. Fertile hybrid results from introgression of the parental gene. Infertile hybrid cause introgression, which removes the pure genes of the elders. Sterile hybrid yields cause a decrease in reproductive capacity resulting in a decrease in population and support species extinction (Allendorf et al. 2012). If the hybrid results are sterile, a decrease in reproductive capacity results in spermatogenesis. The analysis of sperm quality requires further analysis.

TSPY protein structure analysis showed some changes in amino acids that affect changes in protein function and require further analysis. These changes must pay attention to various properties of amino acids, the level of sustainability/conserved, and the percentage of changes (Chavez 2010). Protein is an important component of biological organisms but is prone to errors when DNA replication can cause mutations. Mutations can change phenotypes and have beneficial, damaging, or neutral effects on individual fertility rates (Studer et al. 2013).

TSPY gene expression is limited to male genital cells and neoplastic of the testes (Vinci et al. 2009). The differentiation of genital cells and the maturity of spermatozoa is a complex regulatory process where deregulation results in tumor formation or infertility (Schnieders et al. 1996). Mutations in the TSPY gene can be associated with abnormalities in the development and function of the testes (Vinci et al. 2009). The TSPY region, characterized by protein binding, plays an important role in spermatogenesis through targeting histone for ubiquitination. Ubiquitin is involved in the regulation of transcription, epigenetic modification, and other processes that are important for the formation of normal gametes (Sheng et al. 2014). However, to completely understand changes in the structure of these proteins that cause changes in the function of the TSPY protein which affect fertility (e.g., being sterile/fertile) in hybrid individuals, requiring further research. 


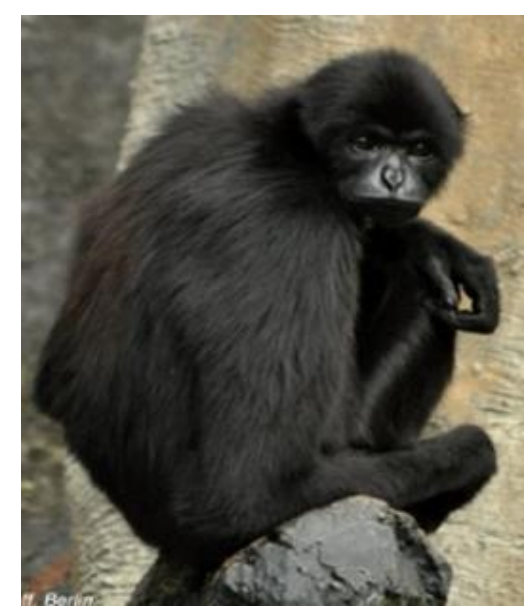

A

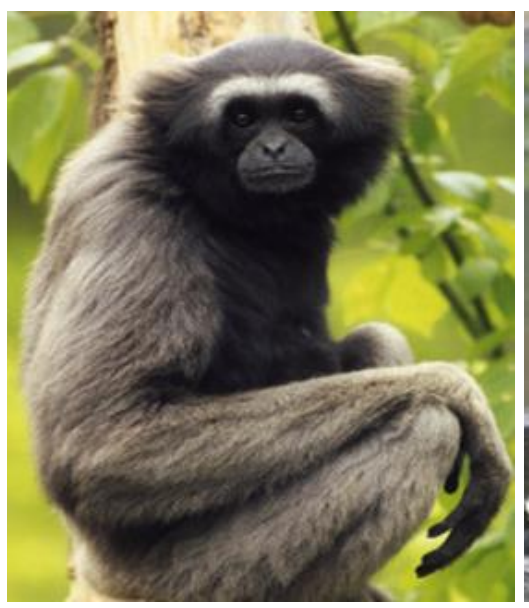

B

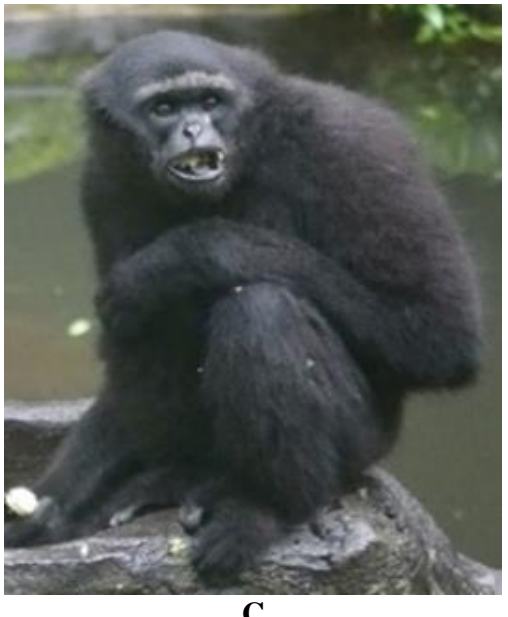

C

Figure 4. Morphologically appearances of: A. Hylobates klossii Nam-Nam (adult female), B. H. muelleri (adult male), C. H. klossii April. Source: A. Klaus Rudolf, Germany; B. http: //zoo.avantia.net/animals/179, C. Personal documentation of RH

Our study gives new insights about paternal and maternal lineage markers by using D-loop MtDNA and TSPY gene to obtain phylogenic between intraspecies and interspecies of Hylobates, specifically. The finding of three-dimensional TSPY protein structures can be used to determine this gene further and its function on male primates. This hybridization case can suggest good management for $H$. klossii preservation in captivity. Efforts to support conservation in the form of genetic information are expected to help conserve species. Genetic information obtained based on male and female parent lineages can provide suggestions for conservation management in maintaining the integrity of species. This is done through the prevention of inbreeding and separating hybrid animals that are indicated to prevent mating with origin species.

\section{ACKNOWLEDGEMENTS}

The authors would like to thank Jansen Manansang. This research is a collaboration between Taman Safari Indonesia (TSI), Bogor, Indonesia and the Primatology Study Program, IPB Graduate School, Bogor, Indonesia. Laboratory analysis was carried out at the Primate Research Center, Lembaga Penelitian dan Pengabdian kepada Masyarakat, Institut Pertanian Bogor (PSSP, LPPM-IPB), Bogor, Indonesia.

\section{REFERENCES}

Allendorf FW, Luikart GH, Aitken SN, 2012. Conservation and the Genetic of Populations. 2nd ed. Wiley-Blackwell, United Kingdom.

Andayani N, Morales JC, Forstner MRJ, Supriatna J, Melnick DJ. 2001. Genetic variability in mtDNA of the silvery gibbon: Implications for the conservation of a critically endangered species. Conserv Biol. 15 (3): 770-775. DOI: 10.1046/j.1523-1739.2001.015003770.x.

Brown WM, George M, Wilson AC. 1979. Rapid evolution of animal mitochondrial DNA. Proc Natl Acad Sci USA 76 (4): 1967-1971. DOI: 10.1073/pnas.76.4.1967.
Chan YC, Roos C, Inoue-Murayama M, Inoue E, Shih CC, Vigilant L. 2012. A comparative analysis of $y$ chromosome and mtDNA phylogenies of the Hylobates gibbons. BMC Evol Biol 12: 1. DOI: 10.1186/1471-2148-12-150.

Chavez FC. 2010. The rules of variation: Amino acid exchange according to the rotating circular genetic code. J Theor Biol 264 (3): 711-721. DOI: $10.1016 /$ j.jtbi.2010.03.046.

Detwiler KM, Burrell AS, Jolly CJ. 2005. Conservation implications of hybridization in African cercopithecine monkeys. Intl J Primatol 26 (3): 661-684. DOI: 10.1007/s10764-005-4372-0.

Eriksson J, Siedel H, Lukas D, Kayser M, Erler A, Hashimoto C, Hohmann G, Boesch C, Vigilant L. 2006. Y-chromosome analysis confirms highly sex-biased dispersal and suggests a low male effective population size in bonobos (Pan paniscus). Mol Ecol. 15 (4): 939-949. DOI: 10.1111/j.1365-294X.2006.02845.x.

Ferreira J, Maria B, Cardi S, Minhos T. 2012. Using Genetics as a Tool in Primate Conservation Non-Invasive Genetic Analysis Threats to Primate Conservation Habitat fragmentation. Lambert, Germany.

Groves CP. 1971. Geographic and Individual Variation in Bornean Gibbon with Remarks on the Systematics of the Subgenus Hylobates. Folia Primatol 14: 139-153.

Groves CP. 2001. Primate Taxonomy. Smithsonian Institution Press, Washington DC.

Hall TA. 1993. Bioedit: a user-friendly biological sequence alignment. Inorg Chem Front 4 (11): 1881-1887. DOI: 10.1039/c7qi00394c.

Holliday TW, Friedl L. 2013. Hominoid humeral morphology: 3D morphometric analysis. Am J Phys Anthropol 152 (4): 506-515. DOI: 10.1002/ajpa.22385.

Hu QX, Fan Y, Xu L, Pang W, Wang S, Zheng YT, Lv LB, Yao YG. 2015. Analysis of the complete mitochondrial genome and characterization of diverse NUMTs of Macaca leonina. Gene 571 (2): 279-285. DOI: 10.1016/j.gene.2015.06.085.

KLHK. Kementerian Lingkungan Hidup dan Kehutanan. 2018. Peraturan Menteri Lingkungan Hidup dan Kehutanan Republik Indonesia Nomor 106 Tahun 2018 tentang Perubahan Kedua Atas Peraturan Menteri Lingkungan Hidup Dan Kehutanan Nomor P.20/Menlhk/Setjen/Kum.1/6/2018 Tentang Jenis Tumbuhan dan Satwa Yang Dilindungi. KLHK, Jakarta. [Indonesian]

Kumar S, Stecher G, Tamura K. 2016. MEGA7: Molecular Evolutionary Genetics Analysis Version 7.0 for Bigger Datasets. Mol Biol Evol 33 (7): 1870-1874. DOI: 10.1093/molbev/msw054.

Kundu S, Ghosh SK. 2015. Trend of different molecular markers in the last decades for studying human migrations. Gene 556 (2): 81-90. DOI: 10.1016/j.gene.2014.12.023.

Masy'ud B, Ginoga LN. 2016. Konservasi Eksitu Satwa Liar. Ed ke-1. IPB Press, Bogor.

Mondal R, Ghosh SK. 2013. Accumulation of mutations over the complete mitochondrial genome in tobacco-related oral cancer from 
northeast India. Mitochondrial DNA. 24 (4): 432-439. DOI: 10.3109/19401736.2012.760551.

Quinten MC, Nopiansyah F, Hodges JK. 2015. First estimates of primate density and abundance in Siberut National Park, Mentawai Islands, Indonesia. Oryx 50 (2): 364-367. DOI: 10.1017/S0030605314001185.

Schnieders F, Dörk T, Arnemann J, Vogel T, Werner M, Schmidtke J. 1996. Testis-specific protein, Y-encoded (TSPY) expression in testicular tissues. Hum Mol Genet. 5 (11): 1801-1807. DOI: 10.1093/hmg/5.11.1801.

Sheng K, Liang X, Huang S, Xu W. 2014. The role of histone ubiquitination during spermatogenesis. Biomed Res Intl 2014. DOI: $10.1155 / 2014 / 870695$.

Singh M, Kaumanns W, Umapathy G. 2012. Conservation-oriented captive breeding of primates in India: Is there a perspective? Curr Sci 103 (12): 1399-1400

Stoneking M. 2000. Hypervariable sites in the mtDNA control region are mutational hotspots. Am J Hum Genet 67 (4): 1029-1032. DOI: $10.1086 / 303092$.

Studer RA, Dessailly BH, Orengo CA. 2013. Residue mutations and their impact on protein structure and function: Detecting beneficial and pathogenic changes, Biochem J 449 (3): 581-594. DOI: 10.1042/BJ20121221

Vinci G, Brauner R, Tar A, Rouba H, Sheth J, Sheth F, Ravel C, McElreavey K, Bashamboo A. 2009. Mutations in the TSPYL1 gene associated with 46, XY disorder of sex development and male infertility. Fertil Steril 92 (4): 1347-1350. DOI: 10.1016/j.fertnstert.2009.04.009.

Whittaker DJ. 2005. Evolutionary Genetics of Kloss's Gibbons (Hylobates klossii): Systematics, Phylogeography, and Conservation. [Dissertation]. Michigan State University, East Lansing, MI.

Whittaker, Geissmann T. 2008. Hylobates klossii. The IUCN Red List of Threatened Species 2008: e.T10547A3199263. DOI: 10.2305/ IUCN.UK.2008.RLTS.T10547A3199263.en.

Whittaker DJ, Morales JC, Melnick DJ. 2007. Resolution of the Hylobates phylogeny: Congruence of mitochondrial D-loop sequences with molecular, behavioral, and morphological data sets. Mol Phylogenet Evol 45 (2): 620-628. DOI: 10.1016/j.ympev.2007.08.009.

Yang J, Zhang Y. 2015. Protein structure and function prediction using ITASSER. Curr Protoc Bioinforma 52: 5.8.1-5.8.15. DOI: 10.1002/0471250953.bi0508s52. 